症例

胃平滑筋肉腫根治術後に発生した難治性肝リンパ漏の 1 治験例

日本医科大学第 2 外科 (主任：庄司 佑教授)

今井茂須田浩充橴谷哲男沾谷純一

胃覀性属㻛に対し胃全摘，脾摘及びリンパ節郭清を施行後，肝リンバ漏に上る難治性 腹水を来した症例を程験した。

術後 6 日目よりドレーンより500 1,100 ml/day の排液があり，保存的療法では改善 傾向が認められないため, 外科的治療を行った. 再手術で P.V shunt 術施行により, 腹 部症状の軽減が認められたが, 発熱, 凝固系の異常を認めたため中止した。再々手術で は、リンバ漏部位に抗生剂を淦布し，腹腔内を生理食塩水で洗浄した。これにより117日

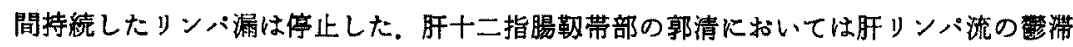
を来さない様に配虑すると共にリンバ管の結禁が重要と思われる。

䅇引用語：肝リソパ漏，難治性腹水，リンパ節郭清

緒

腹部外科手術時のリンパ管損隻に起因するリンバ漏 により発生した難治性腹水は, 腹部大動脈瘤手術 ${ }^{1}$, 胃 癌手衍 ${ }^{2)-6)}$, 膵頭十二指晹切除術 ${ }^{7)}$, 後腹膜リンバ節部 清術帛などで報告されているが，腹水の性状や臨床経 過によって，保存的あるいは外科的治療が行われてい る.

今回, 胃平滑筋肉腫に対し胃全摘術及びリンバ節郭 清術施行後，難治性腹水を来した症例を再々手術によ り治病せしめたので，若干の文献的考察を加え報告す 3.

症例

患者：34歳, 男性.

主訴：嘔気, 全身倦急感.

既往歷と家族歴：特記すへきことなし。

現病歴：昭和62年 1 月頃より，食後嘔気，胃部不快 感を覚えたが放店していた. 5 月に入り当院を受診し， 精龺の結果, 胃粘膜下腫湯之肝機能障害を指摘され治 療のために入院した。

入院时所見：体格・栄養状熊；良好，眼瞼結膜：貧 血 (一), 眼球結膜; 黄㛹 (一), 胸部に理学的異常所 見を認めなかった，腹部は平坦で圧痡なく，肝および

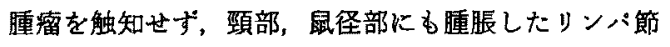
を触知しなかった。

入院時検査所見：表 1 に示す様に肝機能検査に異常

1991年11月29日受付 1992年2月1日採用
表 1 入院時検查所园

\begin{tabular}{|c|c|c|c|}
\hline \multicolumn{2}{|c|}{ 末梢血萑像 } & GOT & $227 \mathrm{IU} / 1$ \\
\hline WBC & $6300 . / \mathrm{mm}^{3}$ & GPT & $421 \mathrm{IU} / 1$ \\
\hline $\mathrm{RBC}$ & $484 \times 10^{4} / \mathrm{mm}^{3}$ & ALP & $8.5 \mathrm{~K}-\mathrm{AU}$ \\
\hline $\mathrm{Hb}$ & $16 \mathrm{~g} / \mathrm{dl}$ & $r$-GTP 2 & $2530 \mathrm{IU} / 1$ \\
\hline $\mathrm{Ht}$ & $45.8 \%$ & LDH & $391 \mathrm{IU} / \mathbf{I}$ \\
\hline plt & $18.2 \times 10^{4} / \mathrm{mm}^{3}$ & Ch-e & $1.09 \Delta \mathrm{PH}$ \\
\hline \multicolumn{2}{|c|}{ 生化学榙查 } & LAP & $322 \mathrm{G}-\mathrm{RU}$ \\
\hline$T-p$ & $7.4 \mathrm{~g} / \mathrm{dl}$ & \multicolumn{2}{|l|}{ 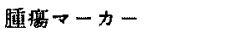 } \\
\hline $\mathbf{T}-\mathbf{b}$ & $0.66 \mathrm{mg} / \mathrm{dl}$ & CEA & $1.1 \mathrm{ng} / \mathrm{dl}$ \\
\hline TTT & $6.2 \mathrm{KU}$ & AFP & $113 \mathrm{ng} / \mathrm{dl}$ \\
\hline ZTT & $13.7 \mathrm{KU}$ & & \\
\hline
\end{tabular}

值を認めるが，その他は正常値であった。

胃透視所見：噴門部後壁に壁外性の隆起があり，粘 膜面に異常はないか，その頂部にパリウムの眝まりを 認め，胃粘膜下尰湯と診断した。

内視鏡所見：喷門部直下小警寄り後壁に $18 \mathrm{~mm}$ 大の 頂部に軽度の陥凹を伴った粘膜下腫湯を認めた。生検 の結果は Group II であった（図 1).

腹部 CT 所見：肝，脾，珡及び大動脈周国など，特に 異常所見を認めなかった。

以上の検查結果上り肝機能改善を持り，胃粘膜下隀 演の診断で昭和62年 7 月 2 日手術を施行した。

手術所見：腹水なく，触診上, 尰瘍は胃体上部の後

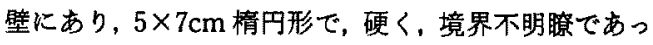
た，さらに、リンパ節は小慗側から肝十二指腸勒帯に かけ遭続して董大していたため，悪性腫湯（悪性リン 


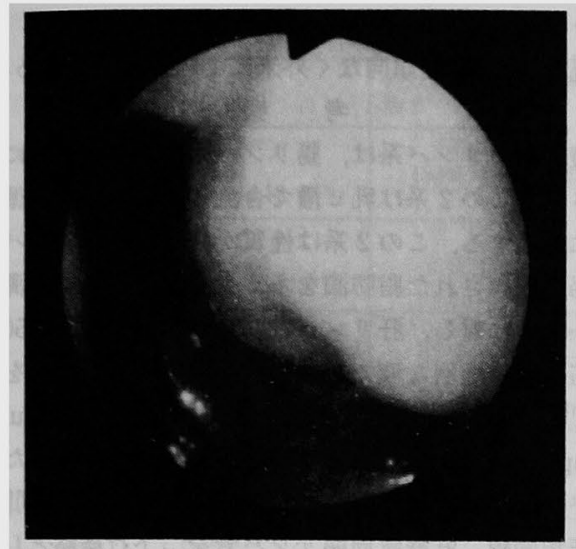

图 1 内視鏡所見：噴門部直下に粘膜下睡瓷を認め た.

ハ董など)を考虑して，胃全摘十脾摘と 2 群及びNo. 12,13のリンバ節の全郭清を行った，再建はRoux-Y 法を用いた. ドレーンを吻合部付近に留置し，閉腹し た.旰は,ほほ正常肝であり他蔵器に転移を認めなかっ た. 胃癌取り扱い規約に準ずると C, Post, $\mathrm{S}_{1}, \mathrm{~N}_{2}$, $\mathrm{H}_{0}$ ， Po， Stage III であった。

病理数糟所見：Leiomyosarcoma without splenic, omental, and lymphnode metastasisの診断であっ た. 畽湯は胃壁より発生している non-epitherial tumor であり長軸で7cm, 発育の仕方は圧排性だが, 一
部漫潤性発育となっていた，組織型は平滑筇原性の spindle cell の増生よりなり, cellularity の高い部位と 低い部位よりなっていた. spindle cell の cellular atypia は cellularity の高い部位にみられ,かつ異形成 核分裂像も認められた。こらの所見より leiomyosarcoma と診断された. また, 隀湯は胃壁外の 脂肪組織近縁にまで達していたが，リンバ節への転移 は認められなかった。

術後経過(図 2)：術後6日目頃よりドレーンから黄 色透明の排液量は増加して $230 － 900 \mathrm{ml} /$ 日となり，最 高排液量は $1,100 \mathrm{ml} /$ 日に達した。術後13日目にドレー ンを抜去し挿入部を閉鎖した。術後10日目より経口摄 取を開始したが，血清蛋白の低下傾向を認めたため IVHによる栄養管理と血漿蛋白製肪の輸夜を行い血 清蛋白の改善及び維持に努めた. ドレーン抜去後 7 日 目に腹水による腹部膨満のため腹水穿刺を施行した。 以後，再手術までに 9 回腹水穿刺 $(1,600 \sim 4,800 \mathrm{ml} /$ 日）を施行している(図3). 穿刺液の性状は細胞診で class I II，細胞成分の $90 \%$ 以はリンパ球であった。 生化学的性状は表 2 の様に総蛋白5.5 7.0と血清総蛋 白値に伴って変動していた（表 2 ).

その後も輸夜, 利尿剤による保存的療法にて改善が 認められないため昭和62年 9 月11日（術後61日目）に 再手術（P.Vシャント術）を施行し肝リンバ漏の自然 治瘱を期待した.

再手術後経過：腹水詝留による腹部賹满はP.V

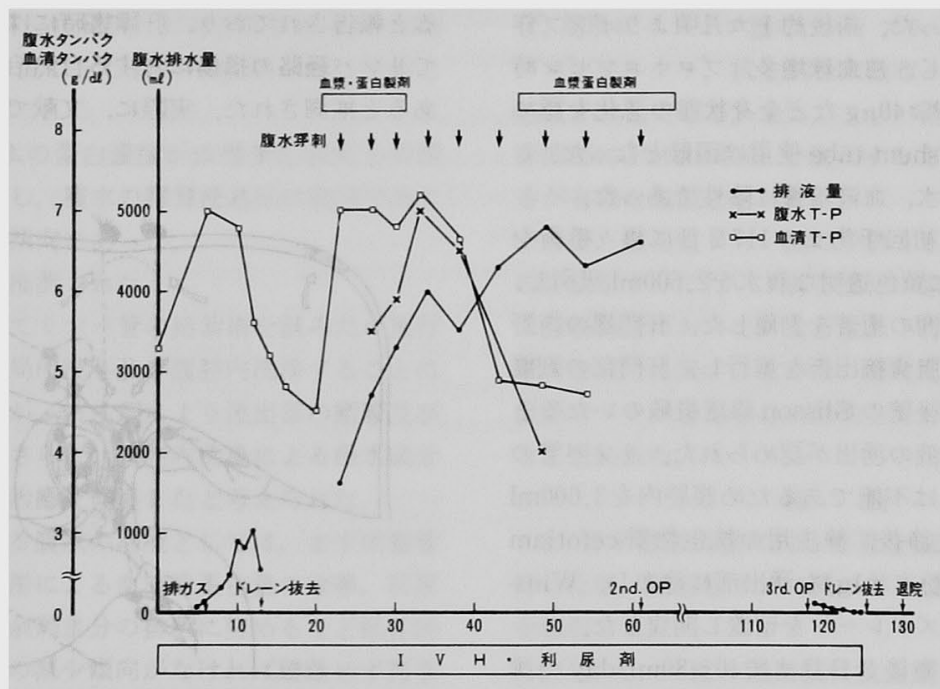

図 2 術後経週 


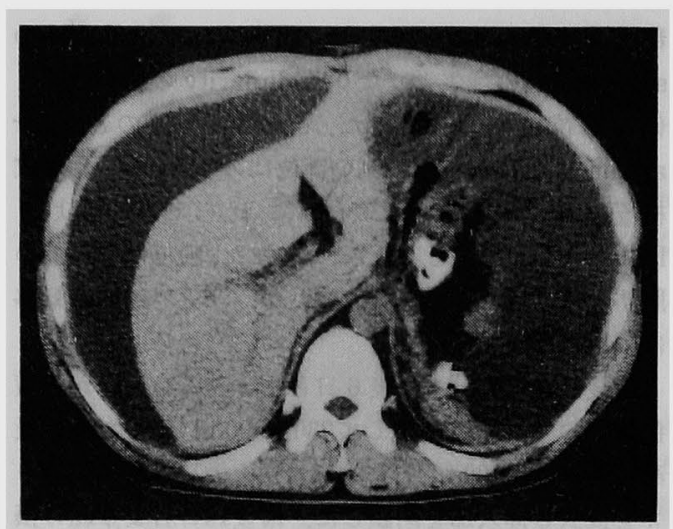

図 3 腹部 CT

表 2 腹水の性状

\begin{tabular}{|c|c|}
\hline 色 調 & 黄色透明一黄色弱晹 \\
\hline リハルタ反応 & $( \pm) \sim(t)$ \\
\hline$T-P$ & $5.5 \sim 7.0 \mathrm{~g} / \mathrm{dl}$ \\
\hline 㜍 置 & $116 \mathrm{mg} / \mathrm{dl}$ \\
\hline ルネベルグ & $1.027 \sim 1.039$ \\
\hline 比 重 & $\mathrm{RBC}(+)$ \\
\hline 沈 查 & WBC $(+)$ \\
\hline & $\begin{array}{c}\text { 小中形練胞 }(+) \\
\text { 陰 栍 }\end{array}$ \\
\hline 培 養 & Class II \\
\hline 細胞晾 & $90 \%$ 以上がリンバ球 \\
\hline
\end{tabular}

shunt tube の手動ポンブ装置により改善されたが，腹 水減少傾向はなかった。術後約 1 力月頃よりポンプ作 動時より発熱を生じ，白血球增多，プロトロンビン時 間 $34 \%$ ，血清 $\mathrm{FDP} \geqq 40 \mu \mathrm{g}$ など全身状態の悪化を認め たため,これ以後 shunt-tube 使用は困難となった。し かし, 発熱時の腹水, 血液培荐は陰性であった。

再々手術所見：初回手術より117日目に再々手術を 施行した。開腹時に黄色透明な腹水を $2,600 \mathrm{ml}$ 吸引し，

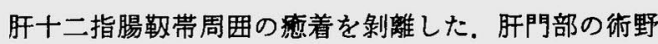
を広くするために胆䂭摘出術を施行し，肝門部の剝離 を進めると肝門部後壁の Glisson 線維組織のいたると ころより、リンバ夜の涌出か認められた。リンパ管の 確認はできず結热は不能であるため腹腔内を $3,000 \mathrm{ml}$ の生理食塩水で洗浄後, 静注用の抗生物質 cefotiam dihydrochloride(粉末状lg)を涌出部に鉒布し, Winslow 孔にペンローズドレーンを留置し開腹した。

再々術後経過：術後 3 日目まで40 $80 \mathrm{ml} /$ day の排 液を認めたがしたいに，減少傾向を示し7日目にはド
レーンを抜去し，その後元気に退院した。

現在, 腹水貯留傾向なく外来にて経過観察中である.

\section{考察}

腹腔内のリンバ系は，腸リンバ系と肝リンバ系に大 別され，この 2 系は乳ビ漕で合流し胸管を経て大循環 系に流入する。この 2 系は性質が異なり，腸リンバは 小腸で吸収された脂肪滴を多く含有し乳白色に混濁し ているのに対し，肝リンパは胸管リンパ流の $20 へ 50 \%$ を占め水様透明な液で血獎とほぼ等しい蛋白成分を含 む910)．肝リンパ管は小葉を取り囲む perinodular lymph space が起始である'1)と言われ，生成されたり ンバは肝リンバ流となり，上行経路として肝鉡状間膜， 肝三角間膜, 肝静脈周囲リン:管を, 下行経路として 肝十二指腸靯帯内リンパを通過する12) (図 4 ).

胃悪性腫場根治術では末梢のリンパ管が多少損傷さ れるはずであるが，側副路の形成，リンバ管静脈吻合 の新生, リンハ管の再生が起こる(13)ため術後のリンハ 漏は自然に減少し消失するのが普通であり，術後に腹 水を生じることはまれである。

さらに，下行性経路断裂による肝リンバ漏はリンパ 管を結愁した場合でも吻合枝を経由して上行性に流 れ、リンハ:管再生も起こり，実験的には約 3 週間で回 復するとされる ${ }^{10}$.一方, 肝障害時には肝小葉内への炎 症性細胞漫潤が生し，肝細胞壊死の結果，小葉内血流 が障害され，類洞内王六谁が起こる。この類洞内压六 進は門脈圧元進の主な原因となると同時に，血䟿成分 の一部が Disse 腔を経てリンバ液となる過程を元進す ると報告されており，肝障害時にはリンバ流が增量し てリンバ経路の損傷に対する自然治瘜を妨げる場合が あると推湘された。実際に，文献では胃癌手術後の肝

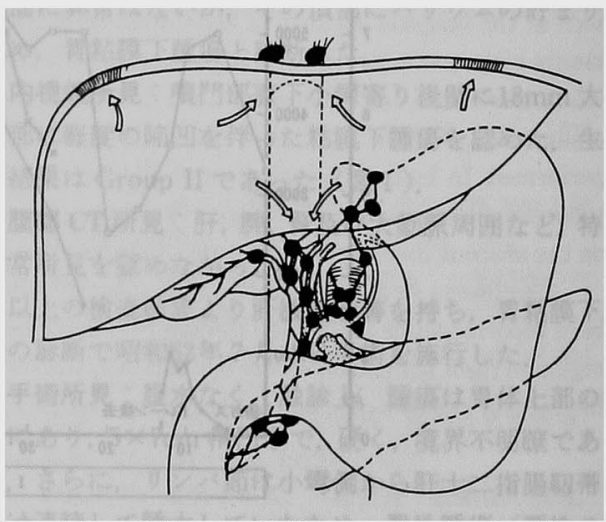

図4肝煘および胆道のリンパ系（三宅 博） 
難治性肝リンバ漏年—

表 3 報告例

\begin{tabular}{|c|c|c|c|c|c|}
\hline & $\begin{array}{l}\text { 病名 } \\
\text { 初回城式 }\end{array}$ & $\begin{array}{l}\text { 势回より再手 } \\
\text { 监までの期間 }\end{array}$ & 再手術法 & 再手術後経過 & 報告者 \\
\hline 1 & 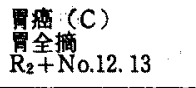 & 183日目 & リンバ管の綖合， & 17PODKドレーン报去，軽快退院 & $\begin{array}{l}\text { 営川5 } \\
\text { (1984) }\end{array}$ \\
\hline 2 & 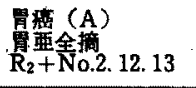 & 35日目 & 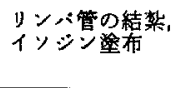 & 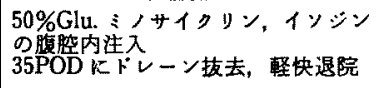 & $\begin{array}{l}\text { 中捣 } 5 \\
\text { (1985) }\end{array}$ \\
\hline 3 & 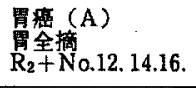 & 47日目 & 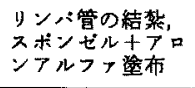 & 14PODKドレーン板去, 軽快退院 & $\begin{array}{l}\text { 中野ら } \\
(1986)\end{array}$ \\
\hline 4 & 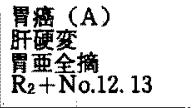 & 101日目 & フィブリン糊䤠布 & 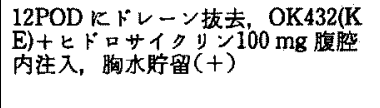 & $\begin{array}{l}\text { 河田 5 } \\
\text { (1989) }\end{array}$ \\
\hline 5 & $\begin{array}{l}\text { 胃䇥 }(\mathrm{C}) \\
\mathrm{R}_{2}+\mathrm{N}_{0.12}\end{array}$ & 105日目 & リンバ管の結紮 & 28PODKドレーン技去, 軽块退院 & $\begin{array}{l}\text { 梅原 } 5 \\
(1989)\end{array}$ \\
\hline 6 & $\begin{array}{l}\text { 胃平滑筇肉腫 C) } \\
\text { 量全摘 } \\
\mathrm{R}_{2}+\text { No.12.13 }\end{array}$ & 117日目 & 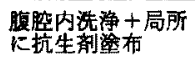 & 7PODにドレーン技去, 軽快退院 & 自椪例 \\
\hline
\end{tabular}

リンハ漏による難治性腹水症の報告は過去20年間で今

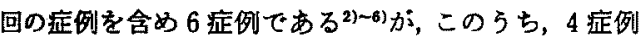
に赫前の肝障害が認められた。

本症例の難治性肝リンハ・漏の原因としては，

1. 征前より肝機能障害があり，街中所見でも部清し た肝十二指腸靬帯のリンバ管は太く、リンバ節が連続 して腫大していた，病理所見でもリンバ節に腫暍の転 移はなく、リンバ管も閉塞されていなかったことなど より肝リンバ流の下行経路が非常に発達していた。

2. 行中㙅作で肝三角間膜, 肝鉡状間膜を結禁・切離 したため、リンパ流の上行経路が遮断された状態と なった.

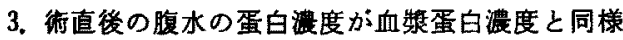
に比較的高値を示し，腹水の膠質漫透殴は高值であり 腹整内水分貯留㑯向にあった。

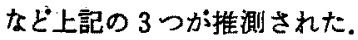

今回，再手術にてリンバ管の結紮術を試みたが施行 できず，抗生郕を局所投与及び腹腔内洗浄することに より治瘦せしめたが，抗生用により流出部の癁着及び 閉塞が促進され，さらに，腹腔内洗净に上る保水成分 の減少がリンパ漏治檍を促進したと考えられた。

肝リンバ漏による腹水の治療としては，まず栄盖管 理や，蛋白剂使用に上る血清総蛋白量の改善，利尿 剂使用に上り体内余剩水分の非泄に努めるなど保存的 療法を試み，腹水の減少傾向がなければ跨躇せず再手 街により漏出リン八管を結禁すべきである。
手術療法に踏及切る時期上しては，保存的療法施行 後で，患者の全身状態が悪化しない5ちに，また，切 離リンパ管を直接確認できる期間が望ましく，早期で あればある结ど良いと思われる。

自験例を含めた報告例の再手術までの期間は45日 〜118日にわたり，保存的療法に費やした期間は比較的 長期間であるため，表 3 に示す様に，再手街により漏 出部位を結禁のみで治疗できた症例は 1 例のみで他症 例は，完全には結愁できないか，または全く結愁でき ず, 局所にインシン㳊布, フィブリン糊，スボンゼル十 アロンフルファ，抗生剂粉末散布十腹空内洗潦などの 処置を加えている。また，リンバ漏部位決定のため， 肝床部に Patent-blue を注入する方法が用いられてい るが有奻な処置と思われた。

今後, 難治性リンバ漏の予防として, 術前の肝機能 の評価を十分に行い，郭清操作に際しては，特に肝十 二指腸勒带において，上行性，下行性の肝リンパ流の

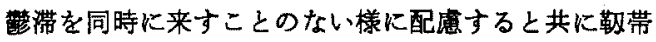
後部のリンパ管を中心に結梦していくことが重要であ ると思われた。

\section{結語}

1）胃平滑筋肉腫に対して胃全摘，リン心節郭清を 行った後, 難治性リンバ漏による腹氷症を来した 1 例 を報告した。

2）肝リンバ液の涌出部に抗生剂を塗布し腹腔内洗 浄を行った所,その後 1 週間で117日間持続した肝リン 
バ漏は揨止しだ。

3）術前に肝機能障害のある場合は肝十二指腸鞄带 のリンバ系が，非常に発達していることがあるため， この部の郭清には十分な注意が必要である。

4）肝十二指腸勒带のリンパ節郭清に際しては,上行 性、下行性の肝リンバ流の㒒滞を同時に来さない様に 配虑すると共に，勒带後部を中心としたリンハ管の結 愁が肝リンバ漏の予防に重要であると思われた。 文献

1) Meinke AH, Esters NC, Erust CB: Chylus ascites following abdominal aneurysectomy. Ann Surg $190: 631,1979$

2）宮川周士，山口時雄，川原央好他：罠癌罢切除後に 発生した難治性リンバ腹水症の1治験例，外科猃 療 $25: 219-225,1983$

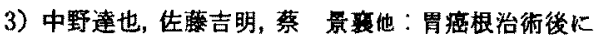

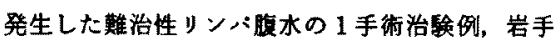
病医会誌 $26: 81-83,1987$

4) 中鳮良作, 藤田敏雄, 白埼 功他：胃癌根治術後に 発生した高度䀒リンバ漏と思われる1手術治倹 例, 臨外 $40: 689-692,1985$

5）梅原靖彦, 宮原 透, 吉田雅行他：胃澏根治術後に
発生した難治性リンバ漏の 1 手術治験例，日消外 会鼓 $22: 2441-2444 ; 1989$

6）河田直海，柬田弘数，松本欤也他：肝硬变を伴亏胃 癌術後に発生した肝リンバ漏の 1 治験例，リンハ 学 $12: 53-57,1989$

7) Walker W: Chylous ascites following pancreaticoduodenectomy. Arch Surg 95;640, 1972

8) Tom TH, Jansen MD: Chylous as cites after retroperitoneal lymphnode dissection. Urology $23: 505,1984$

9) 小谷正彦, 山本 昭：リンパの生化学, 代謝 9: $591-597,1980$

10)钧ス:子，藤川和生，西 厚生：肝リンバ系の形 熊，分布，碳細搆造と機能，日医師会誌 $83: 1229$ $-1236,1980$

11) 朝倉均, 森田 登, 土室雅春：消化器系任占める リンパ管の意義，血と脈管 $1: 1343-1353,1970$

12) Magari $S$, Fujisawa $K$, Mizutani $Y$, et al: Morphological studies on liver lymphatics. Lymphology $12 ; 14-17,1979$

13）小谷正彦：リンバ管の構造と機能，血と脈管 1 ; $1325-1329,1983$

\title{
A CASE REPORT OF INTRACTABLE HEPATIC LYMPHORRHEA FOLLOWING RADICAL OPERATION FOR GASTRIC LEIOMYOSARCOMA
}

\author{
Shigeru IMAI and Hiromitsu SUDA \\ Hazaki-Saiseikai Hospital \\ Tetsuo SHIBUYA, Junichi SHIBUYA and Tasuku SHOUJI \\ Second Department of Surgery, Nippon Medical School
}

A case of intractable ascites due to hepatic lymphorrhea following total gastrectomy, splenectomy and lymph node dissection for a malignant tumor of the stomach is described. Since the 6th day after the operation, the daily amount of ascites from the drainage tube increased from 500 to $1100 \mathrm{ml}$. There was no tendency of healing by the conservative therapy, and the patient was reoperated on.

With the P.V shunt in the second operation, the abdominal symptoms were alleviated, however, this procedure was suspended because of fever, leukocytosis and abnormal ranges of coagulo-fibrinolic system. In the last operation, sprinking of antibiotics over the portion of lymphorrhea and irrigation of abdominal cavity were performed. Owing to these procedures, intractable lymphorrhea lasting 117 days disappeared. In the dissection of hepatoduodenal ligament, it is important to consider so as not to congest the current of the lymph and to ligate the lymphatic vessels. 